\title{
施主ブログに記述された新築の戸建住宅オーナーと庭との関わりについての研究 \\ The Relationship between House Owners and their Gardens: a Content Analysis of Newly-built House Owner's Blogs
}

\author{
矢部 恒彦*
}

Tsunehiko YABE

\begin{abstract}
Why does some house garden have rich vegetation and the others have not? The aim of this study is that give an account of the relationship between house owners and gardens, by using content analysis of newly-built house owner's blogs. There are two approaches as follows; (i.) Quantitative analysis: The author arrange this data sets by topics of the articles. Topics are divided into 10 groups. Then, count the words of topics and locate the topics on the whole time-line of one of the blogs. This shows that, the owners tend to write the topics about "shopping", "order" at early stage of the time-line, and then they write the topics about "gardening work". (ii.) Qualitative analysis: The author slice the articles into the small segments and summarize it in the codes. Then arrange the code map to build up 11 categories and sub-categories. The map shows that, relationship between owners and their gardens is start from "own garden", and next toward "start to work". Then this tendency divided into two directions: "garden work as recreation" and "garden work as housework". These two trends make variation of the relationship from "greenery as home facilities" to "greenery as it is". The relationship between house owners and their gardens: a content analysis of newly-built hose owner's blogs.
\end{abstract}

Keywords: gardening, exterior, qualitative, content analysis キーワード：ガーデニング, 外構, 質的, 内容分析

\section{1. はじめに}

\section{(1) 調査研究の対象と目的}

多くの人々にとって，住宅は一世一代の買い物であろう。住宅 を取得する時，人々は，ローン審査，業者選びなどから始まり， それまでの日常生活には無かった多くのことを体験する。これは 鮮烈な体験のようで，個人が執筆するブログサイトには，住宅の 所有者になるまでの様々な体験が記されている。その中には，高 価な上に, 中古住宅やマンションなどと比べて複雑な買い物とな る戸建住宅の購入体験記が数多くあり，施主ブログと通称されて いる。

施主ブログは，新築の住宅取得を思い立ってから，竣工，引越 し後の生活までを記したオンライン日記という類似した形式を持 つ。ブログのエントリ（日々の日記に相当する一記事）は項目ご とに整理されている場合が多く, 庭関連の項目の中には, 発注, 緑の手入れ，遊び，庭木紹介など，一般の生活者から見た庭につ いてのエントリが掲載されている。

本研究では，施主ブログのうち，庭と植物に関わるエントリが あるものを対象としてテクスト内容分析を行う。これにより，ブ ログに描かれた，一般的な生活者像としての施主と，庭や緑との 関わりを明らかにすることを目的とする。

\section{(2) 既往研究と本研究の意義}

戸建住宅地の庭は重要な緑地である。たとえ，それを庭園だと は言い難いような極小の植栽空間でも，住民に緑との触れ合いを 提供するだけに留まらない重要性を持つ。

高橋らによれば, 1990 年代中盤コンテナ・ガーデニングが日本 で普及した 1)。コンテナは街路に面した場所に置かれることが多 く, 街路からの視線を意識し, 装飾性を志向した緑化が行われて いる 2)。岡田らは，つる性植物による立面緑化を行なっている住 民へのアンケート調査を行い，植物への興味だけではなく，住ま いのイメージアップや立面の装飾を目的として緑化を行なってい ることを明らかにしている ${ }^{3)}$ 。さらに, 戸建住宅団地を対象とし
た権らの調査によると，私有庭の外側にあるアプローチ部分に植 物が置かれるようになって来たことが明らかにされている4)。

このように，住民による緑化は，趣味的，自発的な活動から始 まり，街路周辺を緑で満たす事へと繋がる重要な活動だと位置づ けることが出来るだろう。

しかし一方，人々が住宅を所有して緑のある庭を維持すること は, 容易なことではない。加藤らは, コンジョイント分析によっ て, 庭造りをする際, 住宅の購入予定者は, 緑の質よりも管理労 力を重要視する傾向がある事などを明らかにした 5)。また，内田 によるアンケート調查においては, $65 \%$ の住民が今後の庭園を「十 分管理する」としているが，13\%の住民が庭園管理を「手間がか かかり，やりきれないと回答している 6)。多くの人々が，住宅 所有者として庭と関わりを持っている。このため, 庭は小さくと も豊かな緑地となる場合もあるが，反対に，手間のかかる厄介な 物に留まる場合もある。

施主と庭や緑との関わりの現在形を，文化的な側面から記述す ることで，住宅所有者としての住民が積極的に庭や緑と関わって いくための示唆を得られる点に，本研究の意義があると考えられ る。

\section{2. 施主ブログの調査方法}

\section{(1) 調査と分析の概要}

調査にあたっては, 対象のブログを絞り込み(3 章), 簡便な量的 分析(3 章)の後に, 質的分析(4 章)を行った。具体的には以下の手 順である;

エントリ毎の量的テクスト分析 : エントリ毎の話題について文 字を計数し，ブログにおける話題の変遷を明らかにした。これに より，各ブログごとに概要と傾向を明らかにした。

文章切片毎の質的テクス卜分析 : 質的な分析は, 人々が活動し ながら何を考え，活動の結果をどのように捉えているかを記述す るのに優れている。様々な手順が提案されているが, 総じて, 段

*法政大学社会学部 


\section{表—1ブログ・ランキングサイトの概要}

名称:にほんブログ村 http://www.blogmura.com/

開設 : 2004 年

概要 : ブログ運営者(ブログ主)の登録制

話題のジャンルごとに分かれてブログを登録

当サイトせ各ブログ間のアクセス数を計測し順位付け

表—2 施主ブログの住宅とブログ主

\begin{tabular}{|r|r|l|l|l|l|l|}
$\begin{array}{l}\text { 対象記 } \\
\text { 事(字) }\end{array}$ & $\begin{array}{l}\text { 日V } \\
\text { 日 }\end{array}$ & 竣工 & $\begin{array}{l}\text { 住宅 } \\
\text { 施者 }\end{array}$ & 性別 & 家族 & その他 \\
\hline 8656 & 1236 & 2005.8 & SK-HO & 女性 & 子供有 & \\
\hline 3799 & 1084 & 2010.10 & SK-HO & 女性 & 子供有 & \\
\hline 885 & 860 & 2010.12 & 工務店 & 女性 & 子供有 & 敷地: 100 坪 \\
\hline 6239 & 824 & 2008.10 & 工務店 & 女性 & 子供有 & 地域: 北海道 \\
\hline 2240 & 819 & 2011.2 & SU-R & 男性 & 子供有 & \\
\hline 1127 & 783 & 2011.4 & SK-HO & 女性 & 子供有 & \\
\hline 695 & 730 & 2011.5 & MIT & 女性 & 子供有 & \\
\hline 6147 & 700 & 2007.10 & SK-HI & 男性 & 子供有 & \\
\hline 3679 & 668 & 2010.11 & DAI & 女性 & 子供有 & \\
\hline 2891 & 609 & 2011.1 & DAI & 女性 & 子供有 & \\
\hline 5169 & 581 & 2010.12 & SK-HO & 女性 & 子供有 & \\
\hline 4192 & 576 & 2010.11 & SK-HI & 男性 & 子供有 & \\
\hline 19800 & 565 & 2011.02 & MIT & 女性 & 夫婦のみ \\
\hline 830 & 564 & 2009.10 & SK-HI & 女性 & 子供有 & \\
\hline 1113 & 546 & 2011.4 & A-HB & 女性 & 夫婦のみ & \\
\hline 914 & 537 & 2011.1 & DAI & 女性 & 子供有 & \\
\hline 959 & 533 & 2011.2 & SU-R & 女性 & 子供有 & \\
\hline 657 & 492 & 2010.7 & SK-HO & 女性 & 子供有 & \\
\hline 1091 & 467 & 2010.9 & SK-HI & 女性 & 子供有 & \\
\hline 12235 & 464 & 2009.3 & A-HB & 女性 & 夫婦のみ & \\
\hline 3399 & 457 & 2010.12 & DAI & 女性 & 子供有 & \\
\hline 6678 & 439 & 2011.3 & MIT & 女性 & 子供有 & \\
\hline 5110 & 423 & 2010.12 & SHO & 男性 & 子供有 & \\
\hline
\end{tabular}

※各ブログは, 住宅の施工者毎のランキングに登録されている。

これが[ハウスメーカ名]の場合はイニシャル，もしくは[工務周とした

階的・再帰的に元データを捨象しながら整理・統合しカテゴリを 構築していく点に特徵がある 7)。そこでは，個別の事例を跨ぎ， 書かれたり，話されたりした言葉が総体として持つ傾向，つまり テクスト全体の傾向を明らかにする事を目指寸場合が多い。

本調査においては，第一段階として，大谷による SCAT (Steps for Coding and Theorization)を参考とし, エントリをまとまりの ある文章ごとに切片化し，個別のブログ毎にコーディングをした 8)9)

SCAT は，一人だけの聞き取り調査のテクストなど，比較的小 さな規模のデータに対応した質的分析の手法である。表計算ソフ トのデータ・シートを用いて，文章切片に対して段階的に読みと 考察を行い，切片全体を通じた要約を行う。本調査における利点 は，大量の初期コーディング作業をデータ・シートによって明示 化できる点にあると考えられる。

第二段階として，SCAT で形成された下位コードによって全対 象ブログにおけるコード・ツリーを構築し，コード相互の関係か らカテゴリとサブカテゴリを得た。それは，各ブログを跨いで， 総体としての施主ブログのテクストに描かれた，庭にまつわる出 来事や，感じたり考えたりした事を捨象したデータ群である。こ れを読み解き, 総体としての施主と,庭や緑との関係を記述した。

\section{（2）対象となるブログの選定と特徵}

調査対象データの範囲を確定するため，ブログ黎明期に開設さ れ現在まで活発に運営されている，ブログ専用の人気ランキン グ・サイトを利用した。そこは，数多くのブログ主（ブログの著 者）が，話題分野ごとの人気ランキングに参加し，順位を上げ, それによって新たな閲覧者を誘導することを目指している(表一 1)。本調査では，一般の生活者がブログ主となる [ライフスタイ ル］住まい］分野の下位から, 施主による新築住宅に関するブロ グが登録されている 15 話題分野を選択した。なお, この段階で,
住宅施工業者や造園業者が明示的にブログ主やスポンサーとなっ たものは除外された。

ランキング順位は，ランキング・サイトと各ブログ間の閲覧者 の移動数によって計測されている。本調査では, ランキング・サ イトから各ブログへの移動 PV(ページビューうアクセス)数が多 い，つまり，リンク・サイトを介して数多くの閲覧者を持つ上位 100 位までのサイトに着目した。そこから，複数の話題分野に登 録されたもの，竣工時期が 2011 年 6 月以降のものを除くと，庭 に関連した題名を持つエントリが掲載されたものは 23 ブログ, 一日 400PV 以上閲覧されているものとなった。

一定の閲覧者を持つブログは，個人的な日記であると同時に， 不特定多数の読者を満足させるように記述されていると考えられ る。つまり調查対象は，閲覧者の人気投票による選別と淘汰によ って形成された，多数の一般生活者の庭における行動，考え方， 感じ方に寄り添ったテクストであると言えよう。さらに，住宅新 築という希少なライフ・イベントの日記である事も鑑みれば，総 体としてのテクストには，閲覧者が自己投影できるロールモデル としての施主像が描かれているとも言える。

以上から，調査対象の施主ブログは，施主と，庭や緑との関わ り方を，総体として描いたものだと位置づけることが出来るだろ う。

\section{（3）施主ブログの概要}

調査対象ブログについて, 2011 年 8 月初頭, 住宅の庭に関連し たタイトルを持つ記事の全文を保存し，アクセス順位に応じて各 ブログに ID 番号を与えた(表一2)。また，ブログ主の社会的属性 をおおまかに見るため，自己紹介の記事などから家族構成などを 確認した。対象エントリは，全ブログ平均で約 4200 字であり， 1 日当たりアクセスは 100 位のものでも 400PV 以上あることか ら，閲覧者にとって，十分な読み応えのある文章であることが伺 える。

家族構成などを見ると，新築住宅の施主であるブログ主の多く は既婚者であり,女性, 子供のある者がそれぞれ約 8割となった。 なお，全ての男性ブログ主は既婚・子供持ちである。また，竣工 時期については 2010 年〜 11 年の冬季, 竣工してから調査時点ま で約半年間のエントリをもつブログが, 最頻の調查対象となつた。

\section{3. エントリから見た個別ブログの話題変化}

次に, 調査対象の各エントリにおける主な話題によって, エン トリを分類し文字数を計数した。その結果, 10 話題に分類された (図一 1 中「エントリの話題」)。なお， 1 エントリの長さは平均 346 文字である。

最も多い話題は，ブログ主自身が所有する庭での[作業に関す るもので，全文字数の $30 \%$ を占める。また，住宅・庭の発注主で あるブログ主と，造園の専門家である[業者やりとり]に関する記 事が $20 \%$ 出現した。左記二つの話題は対照的であり, 前者はブロ グ主が直接に庭と関わること，後者は専門家を介して間接的に庭 と関わることを扱っている。

話題[作業]のブログ毎出現率は，40\%以上のブログと $25 \%$ 以下 のブログに大別できる。このため, [作業]出現率が高位群の 10 ブ ログと，低位群の 13 ブログに分けて，ブログの時系列における 話題の変遷を計数した(図-1)。

高位群においては，[作業]が時系列の最初から最後まで満遍な く出現していることが分かる。これに対して, 低位群においては, 時系列の初期に, 話題[業者やりとり]が多く出現していた。つま り高位群は，住宅新築をする際，最初から自らが直接関わるもの として庭を記事化しているのに対して，低位群は，間接的に関わ るものとして庭を記事化している。 
ただし, 低位群においても, エントリ変遷の長いブログ ID67, 95，23については，後半で[作業が出現している。つまり，多く の話題を扱ったブログにおいては，初期では庭への直接的な関わ りがなくても，その後，直接的な関わりが記述されていた。これ は，充分な文章長を持つブログであれば，直接的／間接的いずれ もの庭との関わりが記述されるようになる事を示唆している。こ こから，全ブログは施主と庭に関する様々な関係を全て含むもの と考え，以下 4 章では，全ブログを一つのテクストと見なした質 的分析を目指寸。

\section{4. 質的調査による住宅所有者と庭や緑との関係}

\section{（1）SCAT を参考にした個別ブログのコーディング}

本章では質的調査を行い，施主ブログ総体としての住宅所有者 と庭・緑との関わりについて検討する。第一段階として，個別の ブログをコーディングした。

まず，SCAT を参考にエントリをまとまりのある文章切片に分 割し，5段階の記入を行った(表一3)。この結果，文章切片を，項 目〈4〉「テーマ・概念構成（前後や全体の文脈を考慮して）」の 中に，複数の短文として捨象することが出来た。

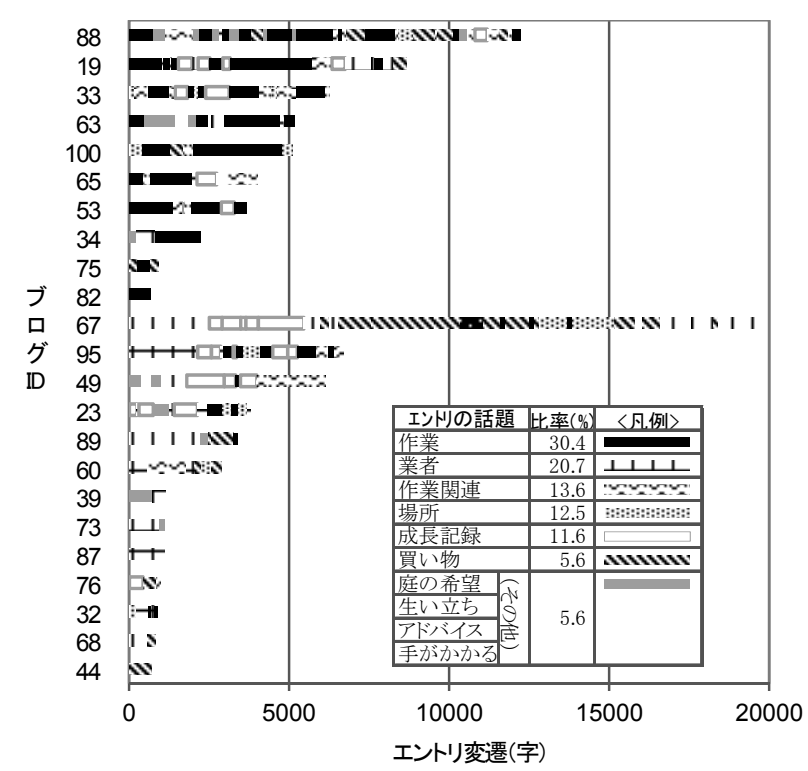

図—1＼cjkstart調査対象ブログの話題変遷

表—3 SCATによるコード化手続きの抜粋

\begin{tabular}{|c|c|c|c|c|c|c|}
\hline \multicolumn{2}{|c|}{$\begin{array}{l}\text { 元デクスト } \\
\text { (ブログID: } 33)\end{array}$} & $\begin{array}{l}\text { <1〉テクストの中の } \\
\text { 注目すべき語句 }\end{array}$ & 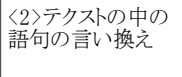 & $\begin{array}{l}\langle 3>\text { 左を説明する } \\
\text { ようなデスト外の } \\
\text { 概念 }\end{array}$ & $\begin{array}{l}\langle 4>\text { テーマ・概念構 } \\
\text { 成(前後や全体 } \\
\text { 文脈老考虑して) }\end{array}$ & $\langle 5\rangle$ 疑問・課題 \\
\hline \multicolumn{2}{|c|}{ 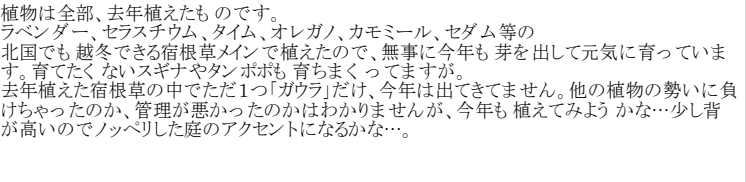 } & 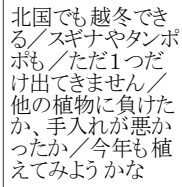 & $\begin{array}{l}\text { ガウラ以外の宿根 } \\
\text { 草は越冬／雑草も } \\
\text { 繁殖 }\end{array}$ & & 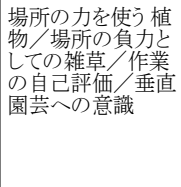 & $\begin{array}{l}\text { 宿根草の名前を列 } \\
\text { 兴しいる。程 } \\
\text { 度の知識があるの } \\
\text { か?? }\end{array}$ \\
\hline \multicolumn{2}{|c|}{ 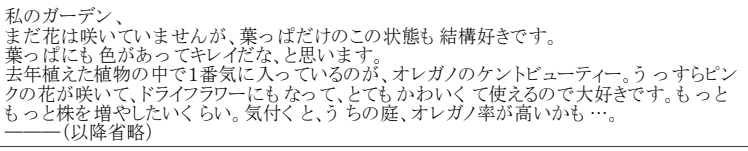 } & 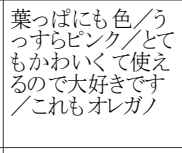 & $\begin{array}{l}\text { 見てよし、ドライフラ } \\
\text { ワーにもなる、料理 } \\
\text { を知らない }\end{array}$ & $\begin{array}{l}\text { 細やかな鑑賞、収 } \\
\text { 穫、食べる }\end{array}$ & $\begin{array}{l}\text { 細やかな鑑賞/収 } \\
\text { 檴/植物を好きに } \\
\text { なる }\end{array}$ & \\
\hline \multicolumn{2}{|c|}{ 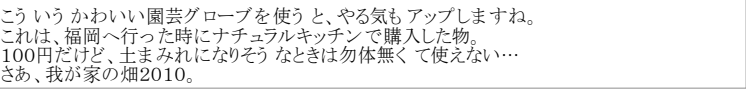 } & $\begin{array}{l}\text { やる気もアップしま } \\
\text { すね尘まみれ }\end{array}$ & $\begin{array}{l}\text { 園芸グローブはカ } \\
\text { ワイが、土まみれ } \\
\text { はもったいない }\end{array}$ & $\begin{array}{l}\text { 作業は土まみれ/ } \\
\text { 放っておくとやる } \\
\text { 気は下がる }\end{array}$ & $\begin{array}{l}\text { 作業のためのショ } \\
\text { "比ソグ/義務的 } \\
\text { な作業 }\end{array}$ & $\begin{array}{l}\text { 楽しみ.義務じちら } \\
\text { に重きを置いてい } \\
\text { るかか? }\end{array}$ \\
\hline \multicolumn{7}{|c|}{ 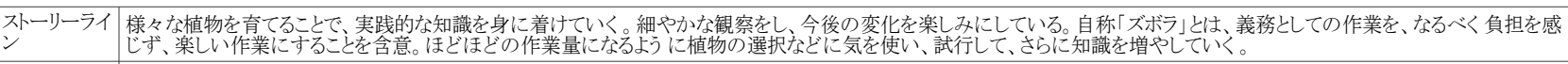 } \\
\hline 論理的記述 & \multicolumn{6}{|l|}{ 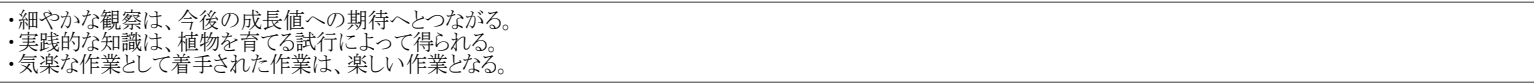 } \\
\hline $\begin{array}{l}\text { さらに追求す } \\
\text { ざき点·課題 }\end{array}$ & \multicolumn{6}{|c|}{ 義務としての作業／楽しい作業の区別は、ほとんど記述されていない。どこから、楽しい作業、となるのか？ } \\
\hline
\end{tabular}

\begin{tabular}{|c|c|c|c|c|c|c|}
\hline \multicolumn{2}{|c|}{$\begin{array}{l}\text { 元テクスス } \\
\text { (ブログID:95) }\end{array}$} & 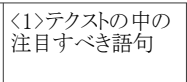 & \begin{tabular}{|l}
$\langle 2\rangle$ テク자中中の \\
語句の言い換え
\end{tabular} & $\begin{array}{l}\langle 3>\text { 左を説明する } \\
\text { ようなデスト外の } \\
\text { 概念 }\end{array}$ & $\begin{array}{l}\langle 4\rangle \text { |テマ・概念構 } \\
\text { 成(前後や全体 } \\
\text { 文脈老考慮して) }\end{array}$ & $\mid\langle 5\rangle$ 疑問・課題 \\
\hline \multicolumn{2}{|c|}{ 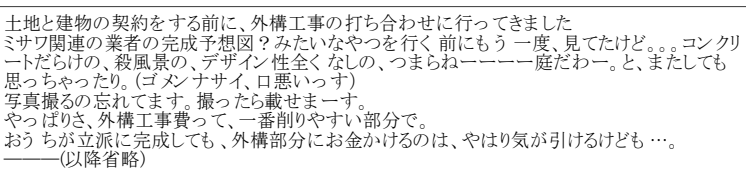 } & 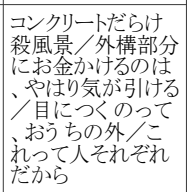 & 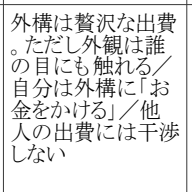 & $\begin{array}{l}\text { 殺風景ではなく } \\
\text { ちょう良い(植物 } \\
\text { 有る)外観。他人の } \\
\text { 外観は否定しない } \\
\text { 。 }\end{array}$ & \begin{tabular}{|l|} 
「お金をかける」外 \\
構／植栽導入／他 \\
人の評価
\end{tabular} & 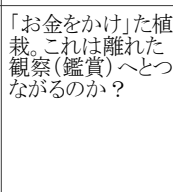 \\
\hline \multicolumn{2}{|c|}{ 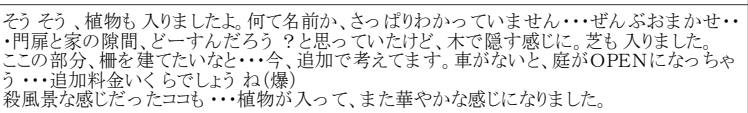 } & $\begin{array}{l}\text { なんて名前か、さ } \\
\text { つぱりかがきせ } \\
\text { ん/庭がOPENに }\end{array}$ & $\begin{array}{l}\text { 植栽の選択は全て } \\
\text { 業者に/仕上がり } \\
\text { の細かい問題点 }\end{array}$ & 植物に興味はない & \begin{tabular}{|l} 
業者植裁に興味な \\
L/外構の空間構 \\
成に着目
\end{tabular} & \\
\hline \multicolumn{2}{|c|}{ 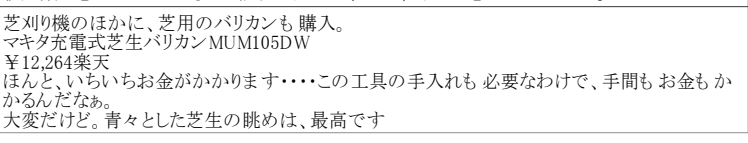 } & $\begin{array}{l}\text { バリカンも購入/ } \\
\text { 手間もお䬬もか } \\
\text { るんだなあ/眺め } \\
\text { は最高です }\end{array}$ & $\begin{array}{l}\text { 莋業のためにの出 } \\
\text { 費/作業の結果に } \\
\text { 満足 }\end{array}$ & $\begin{array}{l}\text { 楽しくない買い物 } \\
\text { 水やり、出費、な } \\
\text { ぞを振り返る }\end{array}$ & 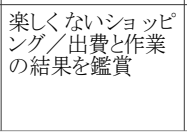 & $\begin{array}{l}\text { ショッピング/出 } \\
\text { 費は対極の関係 }\end{array}$ \\
\hline \multicolumn{7}{|c|}{ 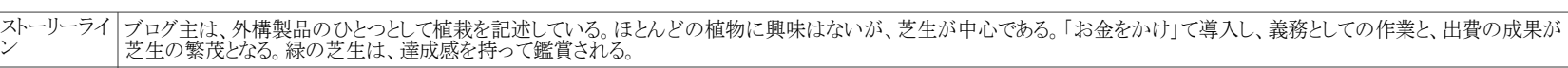 } \\
\hline 論理的記述 & \multicolumn{6}{|l|}{ 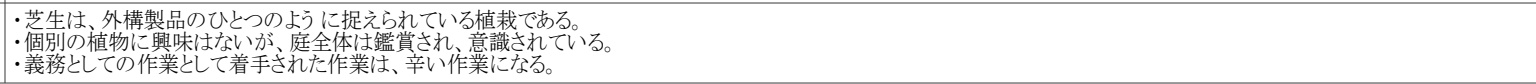 } \\
\hline
\end{tabular}


表—4＼cjkstart文章切片のコードツリー

\begin{tabular}{|c|c|}
\hline 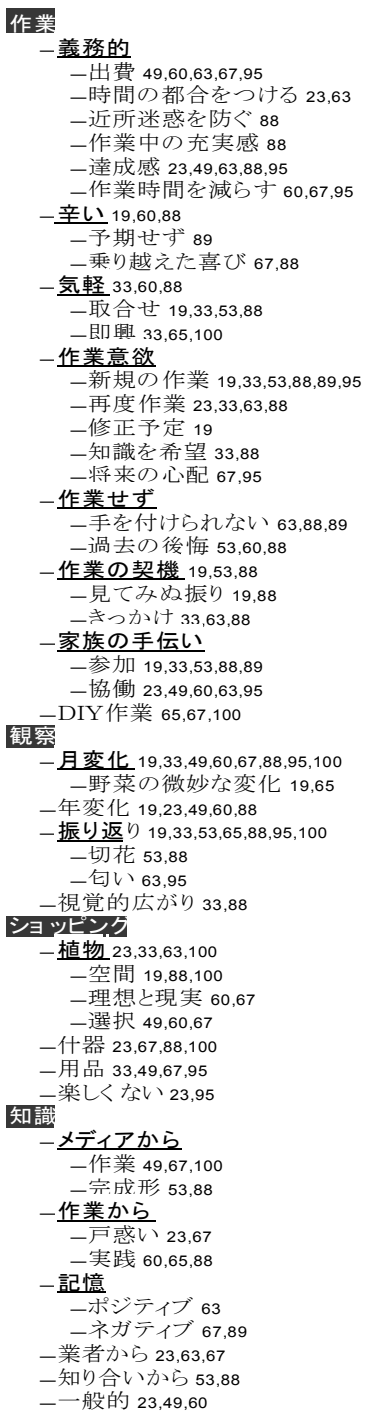 & 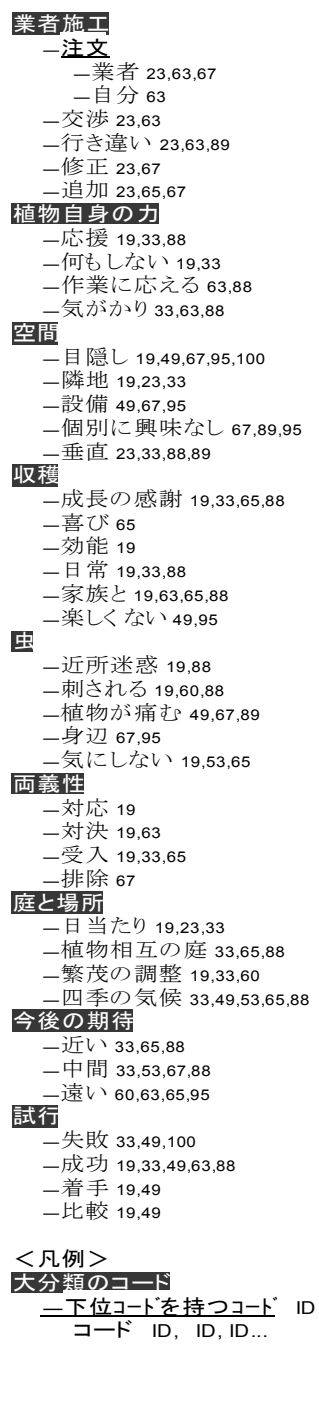 \\
\hline
\end{tabular}

次に，各ブログの項目〈4〉のうち類似したものをまとめ, 代表的な短文をコードとした。さらに，類似したコードをまと めてコード・ツリーを構築した(表一4)。なお，一切片に複数コ ードが与えられる場合もあった。

その結果，ここでもエントリ単位の話題と同じく[作業]，[業 者]，[ショッピング]が大分類としてまとめられた一方，これと は異なり，植物に関する[知識]の習得，庭の[空間]，[収穫，庭 の[虫]に関連した出来事, 植物を成長させる[庭と場所の力, 自 然の[両義性]が大分類となった。大分類は，庭や緑と関連した ブログ主の様々な活動と，庭や緑についての所見によって構成 されている。

コードの下位分類を見ると, 類似した活動や所見についても, 対極的な立場が含まれていた。たとえば，[作業]の下位コード には[作業]-[辛いから[作業]-[意欲というコードまで存在した。

（2）施主ブログ総体における庭や緑との関わり

下位コードには対極的なものも含まれていた。このため，第 二段階として，類似した活動や所見の集合である大部類を超え て，下位コードを相互の関連性に基づいて収集・整理し，ブロ グ総体として検討する。

まず初めに，住宅新築に伴ってブログ主が庭の所有者となる ことから，自分の庭での作業を行うことまでを関連性の出発点 と定め，コードを関連付けていく。具体的には，ブログ主が庭 と緑を所有することを示すコード群からグループ化し，これを カテゴリ：【庭を持つ】とた。次に，所有者は緑に関係する作 業を開始寸る(図-2 矢印 $\mathrm{A}$ )。この作業は，きっかけとなる【作 業:「重い腰」が上がる】に始まり，これは【作業：リクリエー ションとして】と【作業 : 家事労働として】という二つの関連 性の流れに分岐寸る。

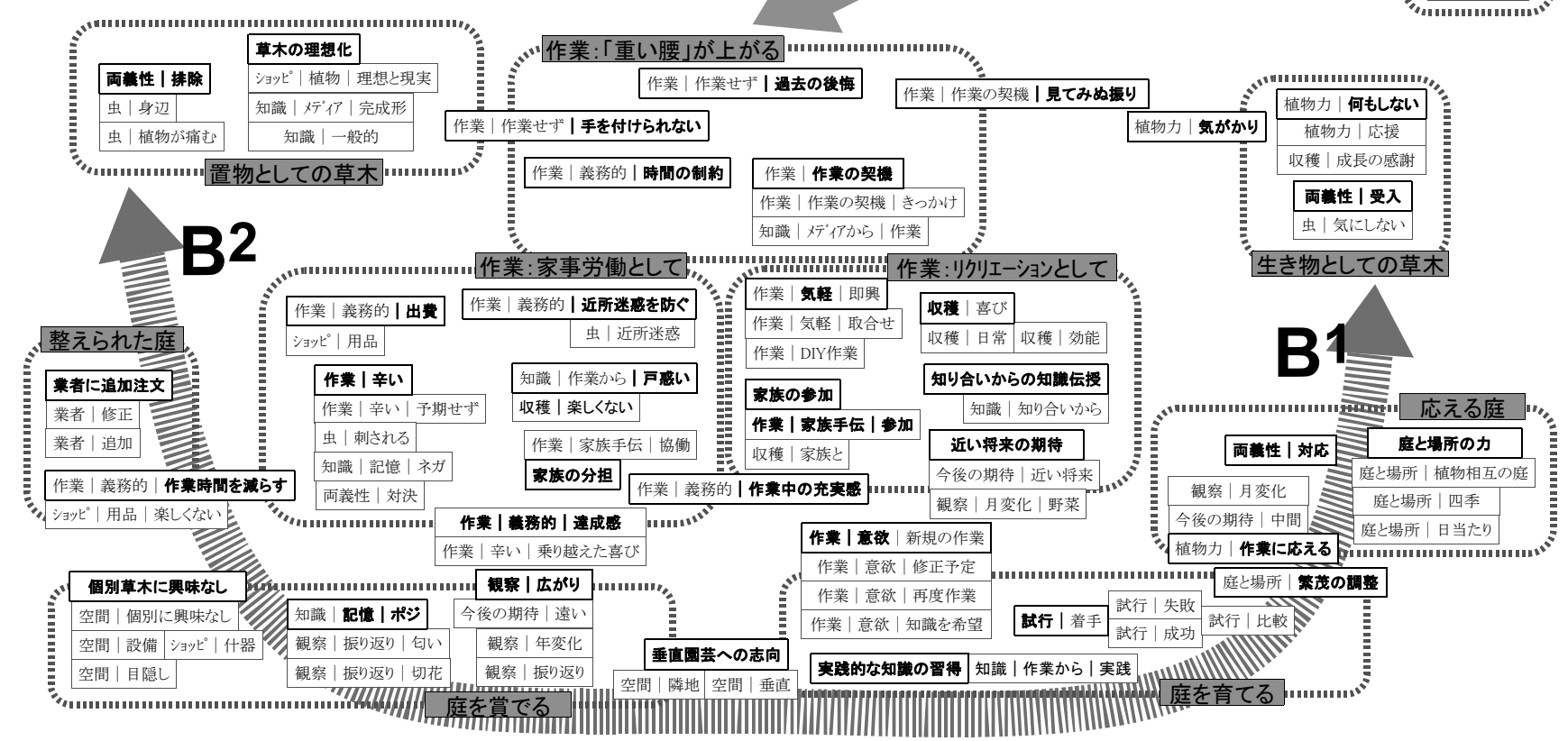

図—2＼cjkstart施主と庭や緑との関わりについてのカテゴリ関連図 
二つの流れは，それぞれ，所有者自らが草木を手入れして【庭 を育てる】ことと，仕上がった【庭を賞でる】こと各々との関連 を持つ。

さらに，【庭を育てる】ことは作業に【応える庭】を介して【生 き物としての草木】へと関連する(図一 2 矢印 $\mathrm{B} 1)$ 。一方，【庭を賞 でる】ことは見栄え良く【整えられた庭】を介して【置物として の草木】へと関連する(図 -2 矢印 $\left.\mathrm{B}^{2}\right)$ 。この，草木自身の生命力 に着目する【生き物としての草木】と，草木を，あたかも庭に配 置された備品のように見なす【置物としての草木】は, 所有者と, 庭や緑との対極的な関わり方と捉えることの出来るカテゴリとな った。

\section{（3）カテゴリごとに見た施主と庭や緑との関わり}

カテゴリの構築と並行して, その中にサブカテゴリ構築し, 代 表的コードを要約しサブカテゴリ名とした(表一5)。以下，これを 詳細に検討寸る。

(i ) A 庭所有の初期

【庭を持つ】施主は草木を購入するが，この際，購入という行 為それ自体が娛楽，つまり[植物のショッピング]となっている。 同じく, [業者への注文]でも，庭所有者は，造園業者とのやりと りをショッピングのように楽しむ。一方，この時点から，[将来の
心配として, 将来の庭作業が負担となるのではないかと予期され ている。

【作業：「重い腰」が上がる】施主は，作業できなかったことを [過去の後悔している。草木は[手を付けられないと意識の外に置 かれるか，反対に，草木が意識されながらも[見て見ぬふり]され ている。所有者の多くは職業を持つなど，作業のためには[時間の 都合をつける]必要がある為である。ここから，何らかの[作業の 契機があって作業開始される。

(ii） $\mathrm{B}^{1}$ 庭を育てる流れへ

【作業:リクリエーションとして】一回限りの[気軽な作業や, 作業の中でも[収穫は，所有者の楽しみとなる。こうした作業で は，配偶者や子供などの[家族の参加]や，植物に詳しい友人など との[知り合いからの知識習得]でのやりとりなど，周囲の人々と 楽しみが共有されている。こうした作業をすることは，作業の成 果として植物が成長することへの[近い将来への期待]へと関連す る。

【庭を育てる】楽しく作業し，その成果を期待する施主は，さ らに新規の作業への[作業意欲を持つ。このような草木への積極 的な関わりが増すことを明示するのは，様々な草木の栽培につい て[試行]することである。こうした作業と成果によって，施主は

\section{表—5カテゴリとサブカテゴリの一覧}

\begin{tabular}{|c|c|}
\hline を持つ & \\
\hline 植物のショッピング & 100 | 八ナミズキ \\
\hline 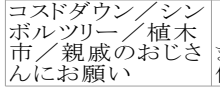 & $\begin{array}{l}\text { まず樹木を購入／ } \\
\text { 作業は親戚 }\end{array}$ \\
\hline 業者への注文 $\mid 67$ & 7 | 紅花エゴノキなど \\
\hline 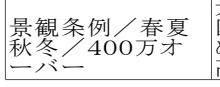 & $\begin{array}{l}\text { 景観条例を守る泉しし } \\
\text { める植栽／金額が } \\
\text { 高い }\end{array}$ \\
\hline 将来の心配 | 95 & シバ \\
\hline 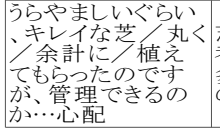 & $\begin{array}{l}\text { 芝生に憧孔て業 } \\
\text { 者に導依賴//他 } \\
\text { の植物も導入 }\end{array}$ \\
\hline
\end{tabular}

\begin{tabular}{|c|c|}
\hline 重い腰」が上が & \\
\hline 過去の後悔 | 53 | & センニチコウ \\
\hline $\begin{array}{l}\text { おう水が足りてなか } \\
\text { った／可哀そうに }\end{array}$ & 夏真会盛りに枯ら \\
\hline 時間の都合をつけ & る|23|シバ \\
\hline $\begin{array}{l}\text { 朝8時以降かな〜 } \\
\text { いて/もが絶対今週 } \\
\text { 末 } \\
\text { 末 }\end{array}$ & 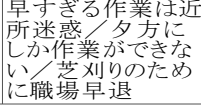 \\
\hline 作業の契機 | 63 & ゴーヤ \\
\hline 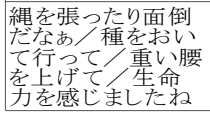 & 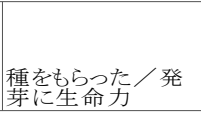 \\
\hline 手を付けられない| & | 89|（特定せず） \\
\hline 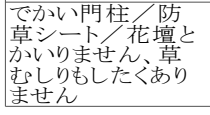 & $\begin{array}{l}\text { なるべく植栽を少 } \\
\text { なく/追加予算へ } \\
\text { の心配 }\end{array}$ \\
\hline 見て見ぬふり 19 & | イチゴ \\
\hline 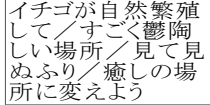 & 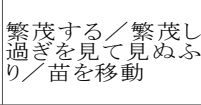 \\
\hline
\end{tabular}

\begin{tabular}{|c|c|}
\hline 置物としての草 & \\
\hline 両義性の排除 & 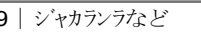 \\
\hline $\begin{array}{l}\text { 新芽の状態 /ア } \\
\text { んムシ来たら許さ } \\
\text { ん }\end{array}$ & $\begin{array}{l}\text { 自分が巽に・購入 } \\
\text { した草に、虫が } \\
\text { ついてほしない }\end{array}$ \\
\hline 草木の理想化 | 67 & 7 | (特定せず) \\
\hline 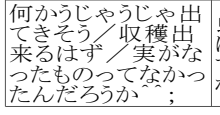 & 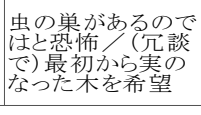 \\
\hline
\end{tabular}

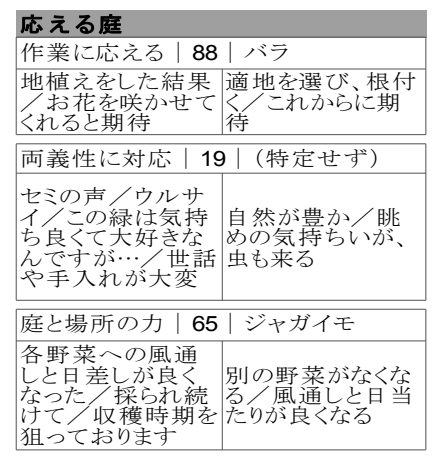

\begin{tabular}{|c|c|}
\hline \multicolumn{2}{|c|}{ 作業: 家事労働として } \\
\hline 近所迷惑を防ぐ| & $88 \mid$ ペチュニア \\
\hline 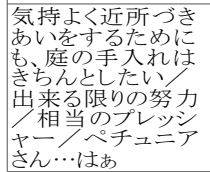 & $\begin{array}{l}\text { 植物で敷地周りを } \\
\text { 活さなだた作 } \\
\text { 業をする }\end{array}$ \\
\hline \multicolumn{2}{|c|}{ 戸惑い| 67 | ジューンベリー } \\
\hline 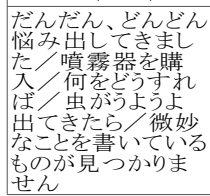 & $\begin{array}{l}\text { 蝍治のための噴 } \\
\text { 霧器業方法 } \\
\text { 分かない：虫 } \\
\text { が嫌い }\end{array}$ \\
\hline \multicolumn{2}{|l|}{ 出費 | 95 | シバ } \\
\hline $\begin{array}{l}\text { 旦那さん毎旦早起 } \\
\text { さして／水道料金 }\end{array}$ & $\begin{array}{l}\text { ブログ主家族が作 } \\
\text { 業/水道料金が } \\
\text { 质にる }\end{array}$ \\
\hline \multicolumn{2}{|c|}{ 幸い作業｜60| シバその他 } \\
\hline $\begin{array}{l}\text { 蚊が大量/水やり } \\
\text { 放育／枯れまえ }\end{array}$ & $\begin{array}{l}\text { 水やりで蚊に刺さ } \\
\text { れる }\end{array}$ \\
\hline 家族の分担 $|63|$ & シバ \\
\hline $\begin{array}{l}\text { 芝生の庭派/ちよ } \\
\text { つとずるいけど／ } \\
\text { なんとかなる }\end{array}$ & $\begin{array}{l}\text { 芝生に憧れ／実 } \\
\text { 家手伝いを見込 } \\
\text { 屯 }\end{array}$ \\
\hline 作業中の充実感 & 88 | ペチュニア \\
\hline 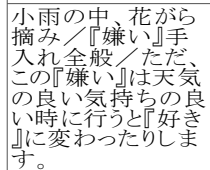 & $\begin{array}{l}\text { 義務的な作業でも } \\
\text { よ気、気持ちの } \\
\text { よい桬しい }\end{array}$ \\
\hline
\end{tabular}

\begin{tabular}{|c|c|}
\hline 庭を賞でる & \\
\hline ポジティブな記憶 & 95 | ローズマリー \\
\hline 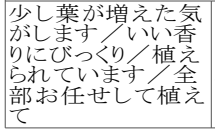 & $\begin{array}{l}\text { 「気がします」詳細 } \\
\text { な観察ではない }\end{array}$ \\
\hline 広がりの観察 | $95 \mid$ & | シバ \\
\hline $\begin{array}{l}\text { 手間もお金もかか } \\
\text { るんだな眺め } \\
\text { は最です高 }\end{array}$ & $\begin{array}{l}\text { 面倒な作業/作 } \\
\text { 羓等果に満足 }\end{array}$ \\
\hline 個別植物に興味な & L \\
\hline $\begin{array}{l}\text { 葉っッとした音つたら } \\
\text { 赤丈夫 } \\
\end{array}$ & 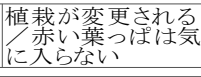 \\
\hline 垂直園芸への志向 & | $\mid 88$ |（特定せず \\
\hline $\begin{array}{l}\text { 高さが需要なんだ } \\
\text { なあ害際に植え } \\
\text { てみるどだ } \\
\text { んいい感じん } \\
\end{array}$ & $\begin{array}{l}\text { 園芸を開始／成 } \\
\text { 長する植物と当 } \\
\text { たりを意識するよう } \\
\text { になる }\end{array}$ \\
\hline 整えられた庭 & \\
\hline 業者に追加注文 & 67 |（特定せず） \\
\hline 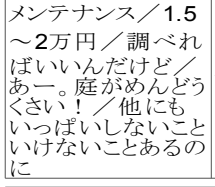 & $\begin{array}{l}\text { 作業する業者を探 } \\
\text { 寸 ブロ主は梌索が得意な } \\
\text { 忧ず }\end{array}$ \\
\hline 作業時間を減らす & | 95| シバ \\
\hline $\begin{array}{l}\text { お金さん、さような } \\
\text { え }\end{array}$ & $\begin{array}{l}\text { 芝刈り機を購入 } \\
\text { 作業の結果に満 } \\
\text { 足 }\end{array}$ \\
\hline
\end{tabular}

\begin{tabular}{|c|c|}
\hline こき物としての & \\
\hline 両義性の受入 $\mid 65$ & 5|キャ心゙ツ \\
\hline 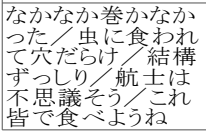 & $\begin{array}{l}\text { 時間をかけて成長 } \\
\text { 出食い }\end{array}$ \\
\hline 何もしない|19|+ & サクランボ \\
\hline $\begin{array}{l}\text { 资々と実が/とこ } \\
\text { 年が年は肥 } \\
\text { 料も何もしなかっ } \\
\text { たのに }\end{array}$ & $\begin{array}{l}\text { 4年目に初めて沢 } \\
\text { 山収穫できた }\end{array}$ \\
\hline 気がかり| $88 \mid$ ミニ & ヒトマト \\
\hline 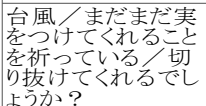 & $\begin{array}{l}\text { 天候が悪くなる } \\
\text { これが収穫で } \\
\text { きるか? }\end{array}$ \\
\hline
\end{tabular}


草木についての[実践的な知識の習得をして, [繁茂の調整をを行う。 【応える庭】施主の作業を受けて, 草木は[作業に応える]成長 力を発揮する。また，人の作業による働きかけではなく，植物同 士の互助や, 庭の日当たり, 四季の気候, 気象の变化など[庭と場 所の力によって草木は成長する。ただし，自然の力は常に喜びを もたらすものではない。たとえば，施主にとって好ましくない悪 天候なども受け入れ，自然の[両義性に対応している。

\section{（iii） $\mathrm{B}^{2}$ 庭を賞でる流れ}

【作業 : 家事労働として】 作業は[出費]を伴い，また，作業に よって草木や虫による[近所迷惑を防ぐ必要がある。このような 関連を持つ作業は，娛楽とは相反する義務的な家事労衝となり， その義務は[家族の分担]となる。また，作業にあたっての[戸惑い] もあり，それは，[辛い作業]一と関連する。ただし，作業をやり 遂げることは，[乗り越えた喜びとなる。なお，義務的な作業に おいても[作業中の達成感はあり，これは，前述の【楽しみとし ての作業】へと再び関連している。

【庭を賞でる】施主は，義務的な作業を完遂することに関連し て，自分が持つ庭の[広がりの観察ををする。これは所有者として の満足感を持った庭全体の鑑賞である。この鑑賞に際しても[ポジ ティブな記憶など，各々の草木と言うよりは，内省的・文芸的な 所見が見られる。また，[個別草木に興味なし]という立場は，草 木との直接的な関わりを減らすことを明示している。ただし， [垂 直園芸への指向]は, 庭全体の鑑賞ともに個別の草木への注目があ り，前述した【庭を育てる】へと関連している。

【庭を整える】義務的な作業に迫られる施主は，[作業時間を減 らす］。れと関連して，造園の専門[業者に追加注文]する。ここ では，施主と草木の直接的な関わりの代わりに，専門業者を通じ た間接的な関わりとなっている。

(iv) 人と草木の 2 つの関わり方

$\mathrm{B}^{1}$ のカテゴリ関連の流れの先に, 人の思い通りにはならない, 人とは別の【生き物としての草木】がある。施主は，人にとって 功罪両面のある自然の[両義性を受入れ]る。そこで人は, 草木に[何 もしないが，これは，草木が意識の外にあるのではなく，[気が かり]に意識しつつも，植物の成長力は，それぞれの草木自身が持 つものと見ているからである。この[気がかり]は, [見て見ぬふり] と関連し，新たな作業の契機へと繋がる。

一方, $\mathrm{B}^{2}$ のカテゴリ関連の流れの先には, エクステリア製品や 備品の，人の思い通りに配置されるような【置物としての草木】 がある。施主は，自然の[両義性を排除]るとともに，生きてい る植物を, 商品カタログにある完成品のように[植物の理想化を している。こうした見方は, 生き物としての草木に[手を付けられ ないことと関連して，庭での作業から施主を遠ざける。

\section{(3) 小括}

本章では総体としてのテクストを捨象したカテゴリ関連図によ り，一般的な生活者としての施主と庭や緑との関わりを明らかに した。その結果，カテゴリ関連は $\mathrm{A}$; 庭所有から庭での作業へ， という連なりで始まり，それは， $\mathrm{B}^{1}$; リクリエーションとしての 作業と，作業に応える庭へ， $\mathrm{B}^{2}$; 義務的な作業と, 整えられた庭 へ, と二分化していた。前者は生き物としての植物，後者は置物 としての植物として，人と草木との対極的な関わり方を示してい る。

\section{5. おわりに}

\section{(1) 本研究のまとめ}

本研究では，施主ブログのうち，庭についての日記のあるもの を対象として内容調査を行った。まずエントリ（一日記）単位で の文字数計量を行い，記事毎の話題の傾向を明らかにした。

次に, 大谷の SCAT を参考に文章切片をコーディングし, さら
に全ブログのコードからカテゴリ関連図を作成した。ここから， テクスト総体としての施主と庭や緑との関わりについて, $\mathrm{B}^{1}$ 庭を 育てる流れと, $\mathrm{B}^{2}$ 庭を賞でる流れに大別することができ, 各々の 延長線上に草木についての対極的な記述がある事などを明らかに した。

\section{（2）住宅の庭園を豊かな緑地とするために}

施主ブログでは，新築住宅という一大ライフ・イベントの合間 に，庭や緑に着目して日記を記している。このため, 庭に関する まとまった記述の無いブログも多数ある中で, 調査対象となった 施主は直接・間接の何れであれ，住宅新築に伴って，主体的に庭 や緑との新たな関わりを築こうとしている者である。

この関わりは, 新築後しばらくすると「生き物」「置き物」とい う人と草木との対極的な関わりへと分化する。つまり，施主は， 庭や緑と二面性を持った関わり方を示寸ようになる。

住宅の庭園を良好な緑地とするためには，まずは $\mathrm{B}^{1}$ の流れ； 作業を通じた所有者と草木の直接的なやり取りを深めることが必 要であろう。また, もう一方の $\mathrm{B}^{2}$ の流れ：庭が美しく維持され 一瞥のもとに鑑賞されることも, 施主の景観体験の質を向上させ るだろう。二つの流れに優劣はない。

しかし, $\mathrm{B}^{2}$ の流れの先に, 植物を排除した庭がある点に留意す べきである。住宅新築の当初, 植物についての知識が乏しい施主 にとって, 素朴な庭の興味と出費が, 庭での義務的な作業と追加 出費という負担になり, $\mathrm{B}^{1}$ への流れが失われてしまう事を避ける 必要がある。 $\mathrm{B}^{1}$ の流れに向からため, まず, 庭の作業を, 苦役と しての家事労衝ではなく, 楽しみとしてのリクリエーションとす るための仕掛けを作ることが鍵となる。

そこで本研究の最後に, 総体としてのテクストから, 個別のブ ログ記事へと再び着目すると，こうした仕掛けへの言及が見られ た。それは, 野菜や果樹といった収穫のできる草木を専門家が導 入する記事である。ただし, その際, 施主との十分な意思疎通が 必要だと考えられる。

\section{参考文献}

1）高橋ちぐさ, 下村孝 (2002) : 杂倠訫・書籍の出版動向及び記事内容 から見たガーデニングブームの実態 : ランドスケープ研究 65 (5), 397-400

2）高橋ちぐさ, 下村孝 (2005) : 京都市左京区の住宅地におけるコン テナガーデニングの実態調査: ランドスケープ研究 68 (5), 473-478

3）岡田準人, 山崎美幸, 下村孝, 深町加津枝 (2006) : 京都市内の戸 建て住宅で実施されている立面緑化の実態 : ランドスケープ研究, 69(5), 795-798

4）権孝姓, 松尾英輔, 高藤博之 (2001) : 専用住宅の門外または玄関 前の植物の配置状況について: ランドスケープ研究 64 (5), 375-378

5)）加藤有理, 今西純一, 深町加津枝, 森本幸裕 (2011) : 住宅購入 検討者の庭園所持や住宅の緑に対寸る意識についての研究 : ランド スケープ研究 74 (5), 551-556

6) 内田均, 佐藤誠樹 (2002) : 東京都内における住宅庭園の植栽管理 実態について : ランドスケープ研究 65 (5), 451-454

7）佐藤郁哉 (2008) : 質的データ分析法 原理・方法・実践 : 新曜社

8) 大谷尚 (2007) : 4 林ップ ーデイグによる質的データ分析手法 SCAT の提案 一着手しやすく小規模データにも適用可能な理論化の手続 き—:名古屋大学大学院教育発達科学研究科紀要 (教育科学), 27-44 9）大谷尚 (2011) : 質的研究シリーズ SCAT: Steps for Coding and Theorization 一明示的手続きで着手しやすく小規模データに適用 可能な質的データ分析手法, 感性工学 10 (3), 155-16 